\title{
The Business School Undergraduate: An Explorative Study of Exposure to Writing and Secondary Research Terminology
}

\author{
Wayne Finley \\ Northern Illinois University \\ Timothy W. Aurand \\ Northern Illinois University
}

\begin{abstract}
Undergraduate students enrolled in a marketing principles class at a large Midwestern university were surveyed to assess their experience in business writing and knowledge of secondary research terminology. The majority of the the respondents were students majoring in business, with the remainder either minoring in business or majoring in a business-related field. The survey consisted of a quiz focusing on secondary research terminology, and questions about the students' exposure to writing research papers. Findings show that many students have limited experience in writing research papers and are unfamiliar with the purpose and authorship of secondary research resources.
\end{abstract}

Keywords: Secondary Research, Information Literacy, Research Skills, Writing Instruction, Business Students, Marketing Students

\section{INTRODUCTION}

As members of the business academy, the fundamental concepts of business writing and secondary research are second nature. Having successfully navigated multiple levels of academia and/or the business world, members of the academy use secondary resources on a regular basis to conduct literature reviews for research or to keep up with industry best-practices. However, business students at the undergraduate level do not have the same exposure to writing and secondary research and may, therefore, struggle with understanding the purpose of these materials for both class research and business strategy. This paper examines undergraduate business students' experience with writing research papers and their knowledge of the basic concepts of information literacy as it pertains to secondary research though the administration of a short survey/quiz on various terms associated with secondary research.

\section{LITERATURE REVIEW}

For students to perform well in both the classroom and the business world, they must possess information literacy/research and writing skills. The Association for College and Research Libraries (ACRL) (2018) defines information literacy as "a set of abilities requiring individuals to "recognize when information is needed and have the ability to locate, evaluate and use effectively the needed 
information." Among the ACRL's list of skills possessed by a person who is information literate are the abilities to both access information and critically evaluate the source of that information (Association of College and Research Libraries, 2018). For this article, the terms research skills and information literacy are used interchangeably.

The need for students to possess research skills, specifically secondary research skills, is of equal importance in the classroom and workplace. The Association to Advance Collegiate Schools of Business (AACSB) acknowledges the importance of workers possessing information literacy skills to function in the workplace (Gilbert, 2017). Phillips (2010) points out that research skills are necessary for students working on consulting projects as part of their business education. Not only does quality student research benefit the clients associated with the project, it also contributes to to the knowledgebase of the students conducting the research (Phillips, 2010).

As students transfer from the classroom to the workforce, they must possess the ability to synthesize information from a wide variety of resources (Gilbert, 2017). These same students also need to understand how to conduct and analyze secondary research in order to solve marketing problems (Lesch \& Hazeltine, 1990), and subsequently communicate their findings in an articulate manner.

Despite scholars acknowledging the need for students to possess secondary research skills to succeed after graduation, there is little discussion in both business and library science literature about the abilities possessed by business students to conduct secondary research for a traditional business course. Additionally, few scholars have attempted to quantify students' familiarity with secondary research resources.

Schaub, Cadena, Bravender, and Kierkus (2017) surveyed undergraduate students at Grand Valley State University and found that most students were unfamiliar with terms commonly associated with information literacy such as journal, catalog, and scholarly. Similarly, Skipton and Bail (2014) surveyed business students to better understand how they conducted research and their familiarity with information literacy terms and sources of information. In both studies, the authors found significant deficiencies among those surveyed in their understanding of research and encouraged further research on the subject.

This paper is an extension of research already conducted on business students and their familiarity with secondary research resources. The authors, having perceived a general deficiency in business students' writing and research, wanted to examine business students' familiarity with secondary research terminology and their exposure to writing research papers. The goal of this research is to gain insights into undergraduate business students' exposure to writing in the classroom and to better understand their research skills. The insights from this research can then be used by business educators to address any deficiencies their students have in order to increase their academic success and prepare them for their future careers.

\section{METHODOLOGY}

In order to explore the undergraduate business students' experience with writing in classroom settings and knowledge of secondary research, a survey was created by marketing and library faculty at a large Midwestern university. Students enrolled in a marketing principles class from the university were asked to take part in a research study focusing on their collegiate writing experiences and knowledge of terminology associated with secondary research resources. Participation in the study was completely voluntary, no course credit or extra credit was provided for participation, and all responses were anonymous. The survey, which received approval from the university's Institutional Review Board, was administered online utilizing Qualtrics survey software. Students who met the same demographic characteristics as the study's target audience pretested the survey, and no significant changes were made to the study following the pretest.

In total, 268 students took part in the study and all completed surveys were deemed acceptable for inclusion in the study and analysis. All participants completed the study in a classroom setting. The course is required of all business students, regardless of major, and is taken as an elective by students with a variety of majors outside of the college of business. Students majoring in Accountancy, Finance, 
Management, Marketing, and Operations Management and Information Systems accounted for nearly $84 \%$ of participants. The remainder of the respondents were either students minoring in business or students majoring in a business-related field such as Fashion and Textile Merchandising and Hospitality. Over $81 \%$ of participants were juniors, and nearly $10 \%$ were seniors. Participants were primarily traditionally-aged college students, with over $88 \%$ being born in 1993 or later.

At the beginning of the survey respondents read a definition of secondary research which they were to refer to when answering the majority of survey questions. The definition read, "For the purposes of this study, conducting secondary research means: Conducting and analyzing data/information which has already been compiled, gathered, organized, and published by others." Participants then answered a series of questions aimed at better understanding their experience in writing research papers and measuring their understanding of terms related to secondary research recourses and the means by which secondary research is obtained. In total, 17 multiple choice questions, each with one correct answer, were asked of the participants. Multiple choice questions about sources of secondary research, the credentials of those authoring peer reviewed journal articles, trade publication articles, and newspaper articles, the intended audience of different resources, the differences between quantitative and qualitative data, using tools for finding secondary research, and the elements of a research paper were included to ascertain the level of understanding that participants had with relatively basic elements of secondary research.

Questions regarding basic participant demographics followed the 17 multiple choice questions. Survey results were analyzed through basic descriptive analysis using SPSS software.

\section{FINDINGS}

As Table 1 illustrates, undergraduate business students have moderate experience with receiving writing instruction and writing research papers. Over $70 \%$ of the respondents, primarily junior year business students, received instruction in conducting secondary research between one and four times, while over three fourths of these students have had at least one class in which they were taught how to

write a research paper. Unfortunately, these same students have had limited experience in actually writing research papers, with nearly $70 \%$ having written between only one and five papers while in college. 
TABLE 1

SECONDARY RESEARCH INSTRUCTION

\begin{tabular}{|l|c|c|c|c|c|}
\hline \multicolumn{1}{|c|}{ Question } & Never & 1-2 Times & 3-4 Times & 5-6 Times & 7+ Times \\
\hline $\begin{array}{l}\text { How often have you } \\
\text { received instruction in } \\
\text { conducting secondary } \\
\text { research while an } \\
\text { undergraduate? }\end{array}$ & $18.25 \%$ & $35.36 \%$ & $37.26 \%$ & $9.13 \%$ & $0.00 \%$ \\
\hline \multicolumn{1}{|c|}{ Question } & Yes & No & $\begin{array}{l}\text { I Don't } \\
\text { Know }\end{array}$ & & \\
\hline $\begin{array}{l}\text { Have you had an } \\
\text { undergraduate class that } \\
\text { taught you how to write } \\
\text { a research paper? }\end{array}$ & $76.87 \%$ & $20.52 \%$ & $2.61 \%$ & & \\
\hline \multicolumn{1}{c|}{ Question } & Zero & $\mathbf{1 - 5}$ & $\mathbf{6 - 1 0}$ & $\mathbf{1 1}$ or More & \\
\hline $\begin{array}{l}\text { How many research } \\
\text { papers (of five or more } \\
\text { pages in length) } \\
\text { requiring secondary } \\
\text { research have you } \\
\text { written during your } \\
\text { undergraduate } \\
\text { education? }\end{array}$ & $10.45 \%$ & $69.40 \%$ & $16.04 \%$ & $4.10 \%$ & \\
\hline
\end{tabular}

$\mathrm{N}=268$

With regard to understanding secondary research, a clear understanding of the difference between quantitative and qualitative data is essential to conducting secondary research in business. As can be seen in Table 2, junior and senior level business students clearly understand the differences between these two types of data with over $85 \%$ of survey participants demonstrating an ability to define both. Admittedly, knowing where to obtain such information may be a far different aspect of secondary research, but having the initial understanding of each type is certainly key to embarking upon a study of any depth.

TABLE 2

UNDERSTANDING OF QUANTITATIVE AND QUALITATIVE DATA

\begin{tabular}{lc}
\hline \multicolumn{1}{c}{ Question } & Percent Correct \\
\hline Description of Quantitative Data & $89.14 \%$ \\
Description of Qualitative Data & $86.89 \%$ \\
\hline
\end{tabular}
$\mathrm{N}=268$

In order to properly conduct secondary research, both in the classroom and in business, students must be able to differentiate among different types of resources. One area of research focuses upon participants' knowledge of reference materials and periodicals: encyclopedias, thesauruses, dictionaries, trade publications, and peer reviewed journals. As can be seen in Table 3, study participants demonstrated a solid understanding of the first three - the encyclopedias, thesauruses, and dictionaries - with approximately $80 \%$ or more of study participants understanding the purpose of each of those resources. However, only half of study participants were able to identify the primary function of trade publications and peer reviewed journals - sources of information more commonly used by business professionals and academicians. 
TABLE 3

RECOGNITION OF TYPES OF PUBLICATIONS

\begin{tabular}{lc}
\hline \multicolumn{1}{c}{ Question } & Percent Correct \\
\hline Purpose of an Encyclopedia & $82.40 \%$ \\
Purpose of a Thesaurus & $84.64 \%$ \\
Purpose of a Dictionary & $79.10 \%$ \\
Purpose of a Trade Publication & $51.12 \%$ \\
Purpose of a Peer Reviewed Journal & $55.22 \%$ \\
\hline
\end{tabular}
$\mathrm{N}=268$

In addition to understanding the purpose of research resources, it is essential to know the general credentials of those who author articles of different types. Table 4 illustrates that business students have a better understanding of trade publication authorship than that of peer reviewed journal articles. Just over a third of respondents were able to properly identify who authors academic works. However, over $90 \%$ of the students have a solid grasp of who writes newspaper articles. Obviously, many college students have had exposure to newspapers before their college careers began, but it would also appear that a similar exposure to trade journals and peer reviewed journals is lacking, at least during the first two-to-three years of the college curriculum.

TABLE 4

RECOGNITION OF PUBLICATION AUTHORS

\begin{tabular}{lc}
\hline \multicolumn{1}{c}{ Question } & Percent Correct \\
\hline Author of a Trade Publication & $65.66 \%$ \\
Author of a Peer Reviewed Journal & $35.82 \%$ \\
Author of a Newspaper Article & $93.61 \%$ \\
\hline $\mathrm{N}=268$ &
\end{tabular}

Business students' limited understanding of peer-reviewed journals was made even more apparent when study participants were asked to identify the intended audience of these periodicals. In Table 5 one can see that while over $70 \%$ of study participants understand the intended audience of trade publications are industry insiders and professionals, less than $18 \%$ realize that professors and researchers are the primary audience of peer reviewed journals.

TABLE 5

RECOGNITION OF PUBLICATION AUDIENCE

\begin{tabular}{lc}
\hline Question & Percent Correct \\
\hline Intended Audience of a Peer-Reviewed Journal & $17.60 \%$ \\
Intended Audience of a Trade Publication & $72.18 \%$ \\
\hline
\end{tabular}

$\mathrm{N}=268$

In addition to understanding the different types of resources typically used in secondary research and their respective authors, undergraduate students need to know how to locate these resources using a database or library catalog. The majority of undergraduate business students surveyed do not understand which purpose each tool serves. As can be seen in Table 6, less than $50 \%$ of students understand that the primary function of a library catalog is to locate books, and just over $50 \%$ understand that the function of a research database is to find articles. 
TABLE 6

UNDERSTANDING OF A CATALOG AND DATABASE

Question

Use of a Catalog

Use of a Database

$\mathrm{N}=268$

Although there is confusion regarding how one might find secondary information, Table 7 illustrates that over three-fourths of survey participants understand the purposes of an article's abstract and know the purpose of both an index and table of contents. Such an understanding is key to the identification, prioritization, and use of secondary research at any academic level. While this study does not investigate where students garnered this knowledge, it is obvious that a strong majority of undergraduate business students know the basic elements of books, and that abstracts provide summaries of articles.

TABLE 7

\section{UNDERSTANDING OF THE BASIC ELEMENTS OF A BOOK AND RESEARCH ARTICLE}

\begin{tabular}{lc}
\hline \multicolumn{1}{c}{ Question } & Percent Correct \\
\hline Purpose of an Abstract & $77.99 \%$ \\
Purpose of an Index & $75.66 \%$ \\
Purpose of a Table of Contents & $83.58 \%$
\end{tabular}

$\mathrm{N}=268$

\section{CONCLUSIONS}

This study finds that junior and senior undergraduate business students have limited experience in writing research papers. These students also lack a clear understanding of secondary research and do not demonstrate strong information literacy skills.

As discussed earlier, the information literate student must be able to find and evaluate information. Although the overwhelming majority of students surveyed were able to differentiate between quantitative and qualitative data and could identify basic reference materials that are useful for general research, many of those students failed to demonstrate an understanding of trade publications and scholarly journals resources essential for business and academic research. Knowing the credentials of authors is key to successfully identifying which resource to use for a given research paper or project, and the majority of students failed to correctly identify the authors of peer reviewed journal articles. In addition, many students were not able to correctly identify the primary tools used to search for secondary research resources in an academic setting, the catalog and database.

Given the results of the survey, it seems that much can be done to enhance these skills and subsequently improve the quality of research that students produce. Those in the academy must be aware of the limited experience students have with writing research papers, and not take for granted that students may not possess the research skills necessary to conduct collegiate-level research. Providing undergraduate students with information literacy training in what many in the academy would consider elementary in nature is required. Sources of training vary and may be available to students through a variety of methods including face-to-face instruction, video tutorials, online learning modules, etc. However, such instruction is necessary for students if they are to succeed at the collegiate level and in their careers as business professionals. 


\section{STUDY LIMITATIONS AND RECOMMENDATIONS FOR FUTURE RESEARCH}

This study dealt only with students from a one large Midwestern university. Secondary research and writing education can vary substantially from one university to another and among majors. Also, this study deals primarily with students in their junior year of study and does not take into consideration coursework taken later in the students' undergraduate education.

Insights from those in the business community with regard to the specific skills demanded by those hiring and employing the workforce are essential for educators who wish to prepare students for their careers. Additionally, details surrounding what is specifically sought regarding secondary research skills based upon industry, vocation, job title, even geographic location, may provide assistance with developing the curricula, and even pedagogy, most appropriate for undergraduate and graduate students would benefit all those involved.

Business educators would also benefit from further studies examining business students' exposure to library instruction, and their comfort with conducting secondary research. At this point, however, we know that many undergraduate business students are unfamiliar with conducting secondary research and writing research papers. Thus, business educators should take into consideration these deficiencies when creating and assigning student research projects. 


\section{REFERENCES}

Association for College and Research Libraries. (2018). Information literacy competency standards for higher education. Retrieved from http://www.ala.org/Template.cfm?Section=Home\&template=/ ContentManagement/ContentDisplay.cfm\&ContentID=33553

Gilbert, S. (2017). Information literacy skills in the workplace: Examining early career advertising professionals. Journal of Business \& Finance Librarianship, 22(2), 111-134.

Lesch, W. C., \& Hazeltine, J. E. (1990). Secondary research, new product screening, and the marketing research course: An experiment in structured decision making. Journal of Marketing Education, $12(1), 30$.

Phillips, C. M. H. (2010). Students' research experiences during consulting projects: Three themes emerging from case studies. Behavioral \& Social Sciences Librarian, 29(2), 91-108.

Schaub, G., Cadena, C., Bravender, P., \& Kierkus, C. (2017). The language of information literacy: Do students understand? College \& Research Libraries, 78(3), 283-296.

Skipton, M. D., \& Bail, J. (2014). Cognitive processes and information literacy: Some initial results from a survey of business students' learning activities. Journal of Business \& Finance Librarianship, 19(3), 181-233. 